Vol. 44, N. 3 : pp. $263-267$, September, 2001

ISSN 1516-8913 Printed in Brazil

\title{
Effect of Flavonoids Morin; Quercetin and Nicotinic Acid on Lipid Metabolism of Rats Experimentally Fed with Triton
}

\author{
Kelly Fabiane Santos Ricardo ${ }^{1}$, Tânia Toledo de Oliveira ${ }^{1}$, Tanus Jorge Nagem ${ }^{2 *}$, Aloisio \\ da Silva Pinto ${ }^{3}$, Maria Goreti Almeida Oliveira ${ }^{1}$ and José Francisco Soares ${ }^{4}$ \\ ${ }^{I}$ Departamento de Bioquímica e Biologia Molecular, Universidade Federal de Viçosa, 36571-000; Viçosa - MG, \\ Brazi; ${ }^{2}$ Departamento de Química da Universidade Federal de Ouro Preto, 35400-000; Ouro Preto - MG, Brazil; \\ ${ }^{3}$ Departamento de Veterinária da Universidade Federal de Viçosa, 36571-000; Viçosa - MG, Brasil; Departamento \\ de Matemática e Estatística da Universidade Federal de Minas Gerais, 31270-000; Belo Horizonte - MG, Brasil
}

\begin{abstract}
Atherosclerosis is a coronary disease where deposition of lipids in the arteries leads to problems of blood circulation. The present work evaluates the action of the flavonoids morin, quercetin and nicotinic acid isolated in association on lipid metabolism in hyperlipidemic rats. Blood serum levels cholesterol, cholesterol-HDL, and triacylglycerids have been analysed following the intraperitoneal administration of the flavonoid compounds dissolved in propyleneglycol by in doses of $5 \mathrm{mg} / \mathrm{kg}$ body weight. Quercetin presented the largest percentual reduction of cholesterol. The best results for cholesterol-HDL have been obtained with-nicotinic acid alone while morin-nicotinic acid combination showed the best triacylglycerols results. Results showed that flavonoids could be beneficious in the treatment of coronary diseases.
\end{abstract}

Key words: Morin, Quercetin, Nicotinic Acid, Lipid, Cholesterol, Cholesterol-HDL, Triacylglycerols, Rats, Hyperlipidemic

\section{INTRODUCTION}

Arterial hypertension, tobaccoism, hypercholesteraemia, obesity, intolerance to glucose (insulinic resistance), hipertryglyceridaemia, low levels of blood cholesterol-HDL $(<35 \mathrm{mg} / \mathrm{dl})$, elevated levels of $\alpha$-lipoproteins, rich diet ingestion (excessive and regular ingestion of cholesterol, saturated fat and refined sugar), hyperuricemia and elevated levels of fibrinogen in the blood are regarded as main causes of cardiovascular diseases. Successive treatments to prevent atherosclerosis combine lifestyle alterations, pharmacological interventions (impaired platelets, antihypertensives drugs, anticoagulants, beta-blockers, estrogenic therapy) and vascular surgeries (Leite, 1994).

Considering treatments the flavonoids, a group of polyphenolic compounds found mainly in plants of the leguminosae family, have been shown to exhibit a series of biological effects among which stand out the inhibition of lipid peroxidation and platelet aggregation, due to their antioxidant properties and their ability of removing free radicals and chelating divalent cations (Cavallini et al, 1978, Lackeman et al, 1986, Fraga et al, 1987. Affana's et al, 1989, Hanasaki et al, 1994, Frankel et al, 1993).

Since the discovery that Triton WR 1339 causes hyperlipidemia in experimental animals, the detergent has widespread use as a tool for studying

* Author for correspondence 
lipid metabolism (Kellner et al, 1951, Recknagel, 1967). Early investigators exploited its capacity to block lipid clearance for measuring rates of triglyceride and cholesterol synthesis and, more recently, the inhibitory action of the detergent has been usefully employed for investigating metabolic interrelationships between plasma lipoproteins. We felt that Triton WR 1339 may also prove useful for studying the involvement of apoproteins in triglyceride catabolism since any changes in the composition or concentration of these proteins may be related to the delay in triglyceride catabolism that follows administration of the detergent. Some of the factors that are know to be important in the catabolism of very low density lipoprotein are the peptide components of high density lipoprotein, specifically the A-I and C-II apoproteins. The firs of these (A-I) activates lecithin: cholesterol acyl transferase, an enzyme which is considered responsible for the formation of most of the serum cholesterol esters and which, in cooperation with lipoprotein lipase, is thougth to take part in the conversion of VLDL to the Cholesterol ester rich low density lipoprotein LDL (Ishikawa et al, 1979).

One of their effects is the prevention of the atherogenic oxidation of cholesterol-LDL (Steinberg et al, 1989). However, flavonols and flavones can also inhibit the lipoxygenase (Hope et al, 1983), decreasing the platelet aggregation and reducing thrombocitic tendencies (Gryglewski et al, 1987 and Tzeng et al, 1991).
Jahromi and Ray (1993) observed that pterosupin and liquirritigenin were able to reduce cholesterol, cholesterol-LDL and triacylglycerol levels in Triton-induced hyperlipemic rats. Nicotinic Acid is already part of the therapeutic arsenal for lipid control in humans showing reductive effects on cholesterol, triacylglycerols and cholesterol-LDL while increasing cholesterol-HDL (Seed et al, 1993).

The present work aimed to evaluate the effects of the flavonoids morin, quercetin and nicotinic acid alone and in association on the control of lipid metabolism.

\section{MATERIAL AND METHODS}

In this study male rats of the "Wistar" race, provided by the Department of Nutrition of the Federal University of Viçosa, weighing $200 \pm 20$ g, were used. They received commercial ration Labina and water ad libitum. After an adaptation period of five days to cages with controlled periods of light and darkness of 12 hours, the animals were separated in seven experimental groups eight animals each. They were randomly distributed to receive the treatments as shown in Table 1. Experimental delimitation was entirely randomised for the seven treatments with eight repetitions.

Table 1- Set of experimental groups.

\begin{tabular}{lllllll}
\hline Group 1 & Group 2 & Group 3 & Group 4 & Group 5 & Group 6 & Group 7 \\
\hline Ration & Ration + & Ration + & Ration + & Ration + & Ration + & Ration + \\
& Triton & Triton + & Triton + & Triton + & Triton + & Triton + \\
& & Morin & Quercetin & Nicotinic acid & Morin + & Quercetin + \\
& & & & & Nicotinic acid & Nicotinic acid \\
\hline
\end{tabular}

In order to induce hyperlipemia, Triton (Sigma), dissolved in a physiologic solution of $\mathrm{NaCl}(0,9 \%)$ was administered intraperitoneally in rats in doses of $300 \mathrm{mg} / \mathrm{kg}$ body weight. After 24 hours morin, quercetin and nicotinic acid (Sigma) were administered alone and or association as shown on Table 1. These compounds were dissolved in propyleneglycol and supplied intraperitoneally in doses of $5 \mathrm{mg} / \mathrm{kg}$ body weight. After another 24 hours, the animals were anaesthetised by inhalation of ethyl ether and blood samples were taken via heart puncture. The samples were centrifuged at $7100 \mathrm{~g}$ during 15 minutes in order to obtain the serum which was analysed for cholesterol and triacylglycerols following the method described by Henry (1982) and cholesterol-HDL following the method described by Lima et al. (1985). Quantitative analysis carried out using a Hitachi spectrophotometer.

Statistical interpretation was carried out using Tuckey and Dunnet tests.

\section{RESULTS AND DISCUSSION}

Tables 2, 3 and 4 show the results obtained from analysing the serum samples. The effects of the 
different treatments are expressed as percentual variations of the serum lipid values from the control group 2 of Triton-induced hyperlipemic rats.

Table 2 - Average values of serum cholesterol in male Wistar rats and percentual variations as result of the treatments.

\begin{tabular}{lrl}
\hline Groups & Colesterol $(\mathrm{mg} / \mathrm{dl}) *$ & $\%$ variation \\
\hline 1 (Ration) & $26.36 \pm 0.70$ & \\
2 (Ration + Triton) & $262.11 \pm 13.96$ & \\
3 (Ration + Triton + Morin) & $88.58 \pm 1.74 \mathrm{bc}$ & $-66.21 * *$ \\
4 (Ration + Triton + Quercetin) & $83.61 \pm 1.89 \mathrm{c}$ & $-68.10 * *$ \\
5 (Ration + Triton + Nicotinic Acid) & $135.13 \pm 2.54 \mathrm{a}$ & $-48.45 * *$ \\
6 (Ration + Triton + Nicotinic Acid + Morin) & $90.58 \pm 2.16 \mathrm{bc}$ & $-65.44 * *$ \\
7 (Ration + Triton + Nicotinic Acid + Quercetin) & $108.57 \pm 1.57 \mathrm{~b}$ & $-58.58 * *$ \\
*Averages followed by the same small block letters do not differ by Tuckey test. $(P>0,05)$. & & \\
$* *$ Statiscally different from the control (Ration + triton) by using Dunnett test $(P<0,05)$. &
\end{tabular}

Table 3 - Average values of serum cholesterol-HDL in male Wistar rats and percentual variations as result of treatments.

\begin{tabular}{lll}
\hline Groups & Cholesterol-HDL (mg/dl) * \% variation \\
\hline 1 (Ration) & $22.25 \pm 0.79$ & \\
2 (Ration + Triton) & $64.20 \pm 0.18$ & \\
3 (Ration + Triton + Morin) & $30.51 \pm 1.31 \mathrm{c}$ & $-52.48 * *$ \\
4 (Ration + Triton + Quercetin) & $29.10 \pm 1.67 \mathrm{c}$ & $-54.03 * *$ \\
5 (Ration + Triton + Nicotinic Acid) & $61.48 \pm 2.09 \mathrm{a}$ & -4.24 \\
6 (Ration + Triton + Nicotinic Acid + Morin) & $38.50 \pm 1.38 \mathrm{~b}$ & $-40.03 * *$ \\
7 (Ration + Triton + Nicotinic Acid + & $33.76 \pm 1.32 \mathrm{bc}$ & $-47.41 * *$ \\
Quercetin) & & \\
*averages followed by the same small block letters do not differ by Tuckey test.(P>0,05). & \\
${ }^{* *}$ Statiscally different from the control (Ration + triton) by using Dunnett test $(P<0,05)$. &
\end{tabular}

Table 4 - Average values of serum triacylglycerids in male Wistar rats and percentual variations as result of the treatments.

\begin{tabular}{lrc}
\hline Groups & Triacylglycerids (mg/dl) * & \% variation \\
\hline 1 (Ration) & $160.68 \pm 2.68$ & \\
2 (Ration + Triton) & $308,90 \pm 2,82$ & \\
3 (Ration + Triton + Morin) & $98.46 \pm 1.56 \quad \mathrm{c}$ & $-68.13 * *$ \\
4 (Ration + Triton + Quercetin) & $126.50 \pm 1.90 \mathrm{~b}$ & $-59.05 * *$ \\
5 (Ration + Triton + Nicotinic Acid) & $166.59 \pm 1.36 \mathrm{a}$ & $-46.07 * *$ \\
6 (Ration + Triton + Nicotinic Acid + Morin) & $88.56 \pm 1.76 \mathrm{~d}$ & $-71.33 * *$ \\
7 (Ration + Triton + Nicotinic Acid + Quercetin) & $119.62 \pm 2.46 \mathrm{~b}$ & $-61.28 * *$ \\
${ }^{*}$ Averages followed by the same small block letters do not differ by Tuckey test.(P>0,05). & \\
${ }^{* *}$ Statiscally different from the control (Ration + triton) by using Dunnett test $(P<0,05)$. &
\end{tabular}

According to the results in Table 2 the animals treated with Triton (group 2), showed a 10-fold increase of average serum cholesterol levels. When submitted to the different treatments, these hypercholesteremic animals showed statistically significant reductions of their cholesterol levels.
Among the treatments carried out, quercetin (group 4) presented the largest percentual reduction in comparison with group 2, as shown by the Dunnet test. These results are in accordance with literature (Maggio, 1956 and Kato \& Tosa, 1983). After statistical classification with Tuckey 
test, it was observed that groups 3,4 and 6 differed only at a level of 5\% probability.

The results on cholesterol-HDL shown in Table 3 showed that the best treatment was obtained with nicotinic acid alone (group 5) as deduced by Tuckey test. This group also showed the best results in the deduction using Dunnet test since it lowered the levels of cholesterol- HDL only by $4.24 \%$, which was of benefit since cholesterolHDL has been responsible for the transport of cholesterol from peripheric circulation to the liver where it is metabolized.

The effects on the increase of cholesterol-HDL are in accordance with results shown in literature (Seed et al, 1993), where humans were treated with nicotinic acid. The mechanism of this action is known as inhibiting the lipolysis in the adipose tissue, reducing the esterification of triacylglycerids in the liver, and increasing the activity of the lipoproteic lipase (Witztum, 1996).

Table 4 presents the results of rat serum triacylglycerids. It was found that the treatment with nicotinic acid and morin (group 6) presented the largest percentual reduction of the levels of Triacylglycerids (derived from the Tukey Test) although the other treatments have been statistically significant as well. Group 6 also showed the best results when deduced with Dunnet test. However, the variation of the results of the other tratments were small.

Literature registers that biochanin $\mathrm{A}$ and formonometin reduce the triacylglycerols levels in $35.6 \%$ and $23.5 \%$, tested in male albino rats with hyperlipidemia induced by triton WR-1369 (Siddiqui \& Siddiqui, 1996).

Studies accomplished about the relationship structure-activity of flavonoids on inhibition of lipid peroxidation explained their mechanism of action being based on their structure. The presence of the hydroxyl group at C-3 position of the skeletons of quercetin, miricetin, catequin and morin has been shown to be responsible for the potent inhibitory action on lipid peroxidation (Affana's et al, 1989; Ratty \& Das, 1988; Mora et al, 1990; Morel et al, 1993). When the double bond between the carbons 2 and 3 of the $\mathrm{C}$ ring is hydrogenated, antiperoxidative potential decreases (Cavallini et al, 1978; Ratty \& Das, 1988; Cholbi et al, 1991). The carbonyl group at C-4 position is essential for the antiperoxidant activity (Cavallini et al, 1978; Ratty \& Das, 1988; Morel et al, 1993). The number of hydroxyl groups in the rings $\mathrm{A}$ and B of flavonoids has been shown to be important in the protection against free radicals. It has been shown that the more hydroxyl groups are substituted in the B-ring, mainly at $\mathrm{C}-3$ ', the higher is the antiperoxidative activity (Husain et al, 1987). The hydroxyl groups at the C-5 and C-7 positions of the A-ring and C-3' and C-4' of the Bring and $\mathrm{C}-3$ of the $\mathrm{C}$-ring seem to contribute to the antioxidant action (De Whalley et al, 1990). The flavonoids that have hydroxyl groups at C-2' position, such as morin, have shown antiperoxidative properties (Cholbi et al, 1991). The hydroxyl groups at the C-3 and C-5 of the flavonoid skeleton, like in quercetin and morin, besides the carbonyl group at $\mathrm{C}-4$ can form chelators for iron ions. The ability of flavonoids to kidnap metallic ions contributes to their antiperoxidatives properties, preventing the formation of free radicals (Affana's et al, 1989; Mora et al, 1990).

It could be concluded that quercetin and morin showed potential activities in the reduction of cholesterol and triacylglycerid levels alone or in combination with nicotinic acid, although they have not been so effective in maintaining the levels of cholesterol-HDL.

\section{RESUMO}

Aterosclerose é uma doença coronária onde a deposição de lipídeos nas artérias leva a problemas na circulação sangüínea. $O$ presente trabalho avalia a ação dos flavonóides morina, quercetina e ácido nicotínico isoladamente e em associação no metabolismo lipídico em ratos hiperlipidêmicos. Foram analisados os níveis de colesterol, colesterol- HDL e triacilgliceróis no soro sangüíneo após administração, via intraperitoneal, dos compostos flavonoídicos dissolvidos em propileno glicol na dose de $5 \mathrm{mg} / \mathrm{kg}$ de peso corporal. Quercetina mostrou o maior percentual de redução do colesterol. Para colesterol-HDL, os melhores resultados foram obtidos com ácido nicotínico isoladamente, enquanto a associação morina-ácido nicotínico mostrou os melhores resultados para triacilgliceróis. Os resultados mostraram que os flavonóides podem ser benéficos no tratamento de doença coronoriana.

\section{REFERENCES}

Affana's, E. V. I. B.; Dorozkvo, A. I.; Brodskii, A. V.; Kostyuk, V. A, and Potapovitch, A. I. (1989), Chelating and free radical scavenging mechanisms of inhibitory action of rutin and quercetin in lipid peroxidation. Biochem. Pharmacol; 38: 1763-1769. 
Cavallini, L.; Bindoli, A. and Siliprandi, N. (1978), Comparative evaluation of antiperoxidative action of silymarin and other flavonoids. Pharmacol. Res. Commun. 10, 133-136

Cholbi, M. R.; Paya, M. and Alcaraz, M. J. (1991), Inhibitory effects of phenolic compounds on $\mathrm{CCl}_{4}$ induced microssomal lipid peroxidation. Experientia. 47, 195-199

De Whalley, C. V.; Rankin, S. M.; Hoult, J. R.; Jessup, W. and Leake, D. S. (1990), Flavonoids inhibit the oxidative modification of low density lypoproteins by macrophages. Biochem. Pharmacol. 39, 1743-1750

Fraga, C. G.; Martino, V. S.; Ferraro, G. E.; Coussio, J. D. and Boveris, A. (1987), Flavonoids as antioxidants evaluated by in vitro and in situ liver chemiluminescence. Biochem. Pharmacol. 36, 717720

Frankel, E. N.; Kanner, J.; German, J. B.; Parks, E. and Kinsella. J.E. (1993), Inhibition of oxidation of human low-density lipoprotein by phenolic substances in red wine. Lancet. 341, 454-457

Gryglewski, R. J.; Korbut, R.; Robak, J. and Swies, J. (1987), On the mechanisms of antithrombotic action of flavonois. Biochem. Pharmacol. 36, 317-322

Hanasaki, Y.; Ogawa, S. and Fukui, S. (1994), The correlation between active oxygens scavenging and antioxidative effects of flavonoids free radical. Biol. Med. 16: $845-850$

Henry, J. B. (1982), Diagnósticos clínicos e conduta terapêutica por exames laboratoriais. $16^{\mathrm{a}} \mathrm{Ed}$. I: 226228

Hope, W. C.; Welton, A. F.; Fielder-Nagy, C.; BatulaBernardo, C. and Coffey, J. W. (1983), In vitro inhibition of the biosynthesis of slow reacting substance of anaphylaxis (SRS-A) and lipoxygenase activity of quercetin. Biochem. Pharmacol. 32, 367371

Husain, S. R.; Cillard, J. and Cillard, P. (1987), Hydroxyl radical scavenging activity of flavonoids. Phytochemistry 26, 2489-2491

Ishikawa, T.; Fidge, N. (1979), Changes in the concentration of plasma lipoproteins and apoproteins following the administration of Triton WR 1339 to rats. Journal of Lip. Res. 20, 254-264

Jahromi, M. A . F. and Ray, A. B. (1993), Antihyperlipidemic effect of flavonoids from Pterocarpus marsupium. Journal of Natural Products. 56 (7), 989 - 994

Kato, N. and Tosa, N. (1983), Effects of Dietary Quercetin on Serum Lipids. J. Agric. Biol. Chem. 47 (9), 2119-2120

Kellner, A.; Correl, W. J.; Ladd, A. T. (1951), Susteined hyperlipemia induced in rabbits by means of intravenously injected surface active agents. $J$. Exp. Med. 93, 373-385
Lackeman, G. M.; Claeys, M. ; Wan Gabo, P. G. R.; Herman, A . G. and Vlein Tink, A. (1986), Planta Medica 52, 433-436

Leite, P. F. (1994), Risco Cardiovascular: Fatores metabólicos e nutricionais, diagnósticos e tratamento. Loyola Ed. São Paulo, 1-33

Lima, A. O.; Soares, B. J.; Greco, J. B.; Gallizi, J. and Cançado, J. R. (1985), Química do sangue In: Métodos de Laboratório aplicadas à Clínica. Técnica e Interpretação. $6^{\text {a }}$ ed., Guanabara Koogan, Rio de Janeiro, 47-115

Maggio, G. D. (1956), Azione della quercetina sull'andamento de alcuni Processi patologici sperimentali correlati alla Mallatia arteriosclerótica. Rehivio italiano di science farmacologiche. 28-37

Mora, A.; Paya, M.; Rios, J. L. and Alcaraz, M. J. (1990), Structure-activity relationships of polymethoxyflavones and other flavonoids as inhibitors of non-enzymic lipid peroxidation. Biochem. Pharmacol. 40, 793-797

Morel, I.; Lescoat, G.; Cogrel, P.; Sergent, O.; Pasdeloup, N.; Brissot, P.; Cillard, P. and Cillard, J. (1993) Antioxidant and iron chelating activities of the flavonoids catechin, quercetin and diosmetin on ironloaded rat hepatocyte cultures. Biochem. Pharmacol. 45, 13-19

Ratty, A. K. and Das, N. P. (1988) Effects of flavonoids on non-enzymic lipid peroxidation: structure activity relationship. Biochem. Med. Metabol. Biol. 39, 69-79

Recknagel, R. O. (1967), Carbon tetrachloride hepatotoxicity. Pharm. Rev. 19, 145-208

Seed, M.; O’Connor, B.; Perombelon, N.; O’Donnell.; Reaveley, D. and Knight, B. L. (1993), The effect of nicotinic acid and acipimox on lypoprotein (a) concentration and turnover. Atherosclerosis. 101, 61-68

Siddiqui, M. T. and Siddiqui, M. (1996) Hypolipidemic principles of Cicer arietanum: Biochanin A and Formonometin. Lipids: 11(3), 1975-1978

Steinberg, D. ; Parthasarathy, S.; Carew, T. E.; Khoo, J. C. and Witztum, J. L. (1989), Beyond Cholesterol: Modification of low-density lipoprotein that increases its atherogenicity. New Engl. J. Med. 320, 915-924

Tzeng, S. H.; Ko, W. C.; Ko, F. N. and Teng, C. M. (1991), Inhibition of platelet aggregation by some flavonoids. Thromb. Res. 64, 91-100

Witztum, J. L. (1996), Fármacos usados no tratamento das hiperlipoproteinemias. In Hardmann, J.G. and Limbird, L.E. The pharmacological basis of therapeutics. $9^{\text {th }}$ ed. Macmillan, New York, 643-660

Received: June 17, 1999; Revised: September 13,1999; Accepted: November 26, 2000. 